\title{
Socioeconomic Changes and Land Use and Land Cover of the Northern Region of Rio Grande do Sul, Brazil
}

\author{
Ivan Luís Rovani ${ }^{1}$ (D) 0000-0002-0560-6824 \\ Vanderlei Secretti Decian ${ }^{1}$ (10) 0000-0002-0092-1489 \\ Elisabete Maria Zanin ${ }^{1}$ (i) 0000-0003-0533-9751 \\ Marciana Brandalise ${ }^{1}$ (D) 0000-0003-4062-1584 \\ Franciele Rosset Quadros ${ }^{1}$ (D) 0000-0002-1224-9300 \\ Luiz Ubiratan Hepp ${ }^{1}$ (1) 0000-0002-8499-9549
}

\begin{abstract}
The dynamics of land use and cover at different spatial and temporal scales allows us to evaluate changes in landscapes, socioeconomic system and impacts on the natural environment. Land use and land cover changes and socioeconomic activities of the Northern Region of Rio Grande do Sul, Brazil were analyzed over a 20 -year scale. Using images from the Landsat 5 sensor TM, land use and land cover maps were obtained for 1991, 2001 and 2011, in which agricultural uses, native vegetation and pasture presented a significant difference between the years. We identified two scenarios for the region: the northern portion presents a reduction in agricultural areas and an increase in pasture and native vegetation, while the southern portion presents a constancy of agricultural areas. The predominant agricultural uses and socioeconomic factors determined the major changes in landscape structure. The effects of these changes resulted in a reduction in the area of agricultural uses and expansion of native vegetation and pasture areas.
\end{abstract}

Keywords: replacement use, rural exodus, environmental legislation, agricultural uses, environmental management.

\section{INTRODUCTION AND OBJECTIVES}

Land use and land cover is one of the key aspects of socioeconomic development(Liu, 2018), and in certain landscapes and/or regions it is directly associated with human-directed activities and related to political and socioeconomic functions (Melendez-Pastor et al., 2014; Parcerisas et al., 2012). These functions are considered a series of anthropogenic interventions that are determinant to landscape changes, with the intention of obtaining products and benefits by exploiting environmental resources (Peterson et al., 2014). In turn, these anthropic actions are related to the type of land use and cover, be it forest, agricultural, residential or industrial (Bossard et al., 2000).

Socioeconomic factors and geophysical aspects are the main driving forces behind abandonment of agricultural land, promoting changes in land use and land use patterns (Figueiredo \& Pereira, 2011; Rudel, 2009), with the abandonment of agricultural activities reflecting especially in an increase in vegetation areas (Díaz et al., 2011). Intensified development of socioeconomic activities results in losses in the supply of ecosystem goods and services and limitations in natural resources (Lambin \& Meyfroidt, 2010; Peterson et al., 2014).

The importance of understanding changes in landscape has stimulated interest in developing studies that can assess the impacts and consequences of changes in land use and land cover for mankind and the planet, as well as the increasing interaction between the man-landscape system (Gerlak, 2014; Turner, 2009; Turner et al., 2007). In this way, land use and land use management policies play a key role in identifying, quantifying and monitoring changes in landscape dynamics, as well as in mitigating soil degradation (Gerlak, 2014; Zhang et al., 2014).

Changes in land use and land cover (mainly land substitution) have increased due to environmental and socioeconomic factors such as land degradation, environmental protection programs, rural exodus, as well as market incentives, industrial and economic development, and urbanization of regions (Díaz

${ }^{1}$ Universidade Regional Integrada do Alto Uruguai e das Missões (URI), Erechim, RS, Brasil 
et al., 2011; Hernández et al., 2015). Thus, studies related to the temporal dynamics of land use and cover at various spatial and temporal scales enable analyzing the evolution of the socioeconomic system over time, the relationship with changes in land use and land cover, and the impacts on the environment by different anthropogenic activities (Ottinger et al., 2013; Simon \& Trentin, 2009; Su et al., 2014). In this context, these studies lead to assessments on the interference of land use and cover on the environment from different anthropic activities and the economic interrelationships in time and space.

Our purpose was to analyze changes in land use and land cover in the northern region of Rio Grande do Sul, Brazil, considering a 20-year spatial-temporal scale (1991 to 2011), and the relationship between these changes and the development of socioeconomic activities. Our hypothesis is that changes in land use and land cover and their effects will be determined from changes in the predominant agricultural uses in the region. In addition, socioeconomic factors and public policies will have influenced changes in land use and land cover, generating changes in the landscape composition and configuration of the region.

\section{MATERIALS AND METHODS}

\subsection{Study area}

This study was carried out in the northern region of Rio Grande do Sul, located between the geographical coordinates $27^{\circ} 12^{\prime} 59^{\prime \prime}$ to $28^{\circ} 00^{\prime} 47^{\prime \prime}$ S latitude and $51^{\circ} 49^{\prime} 34^{\prime \prime}$ to $52^{\circ} 48^{\prime} 12^{\prime \prime} \mathrm{W}$ longitude. It has an area of 591,610.00 hectares and covers 31 municipalities (Figure 1).

According to the 2010 Demographic Census from the Instituto Brasileiro de Geografia e Estatística (IBGE), the region has a population of 215,124 inhabitants (IBGE, 2010). It has a significant diversification of land use and cover in activities and appropriation forms and presents great influence in its structuring of socioeconomic factors integrated to its biophysical components. Its economic base is centered on highly-skilled agriculture, mainly with soybean, corn, and wheat cultivation, and raising livestock of poultry, pigs and cattle (Decian et al., 2009). The region is part of the Atlantic Forest Biome and its vegetation is characterized by three types of native vegetation: Atlantic Forest with Araucaria, Semi-deciduous Atlantic Forest, and Pampa (lowlands) and floodplains, considered as components of the Atlantic Subtropical Forest, despite its floristic composition and original physiognomy (OliveiraFilho et al., 2015).

It presents altitudes that vary from $280 \mathrm{~m}$ to $900 \mathrm{~m}$ in relation to the sea level and a predominance of flat to wavy relief in the south of the region, and wavy to sloping relief in the north. The region's climate is characterized as humid subtropical temperate (type Cfa and Cfb of Köppen-Geiger), with average annual temperature of $17 \pm 1{ }^{\circ} \mathrm{C}$, with four well-defined seasons and average annual precipitation that varies between $1,900 \mathrm{~mm}$ and 2,200 $\mathrm{mm}$, with regular rainfall well distributed throughout the year (Alvares et al., 2013).
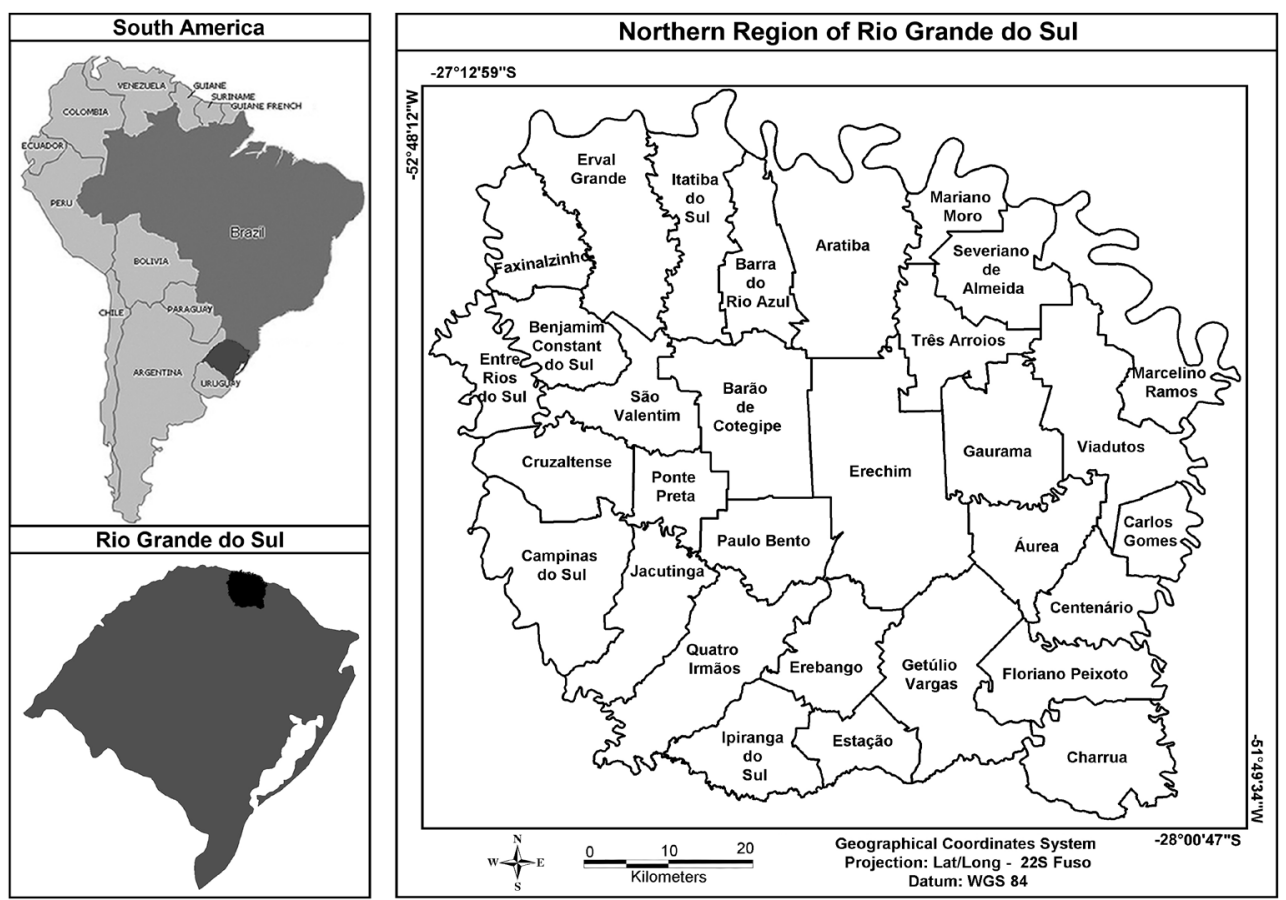

Figure 1. Location and geopolitical boundaries of the northern region of Rio Grande do Sul, Brazil. 


\subsection{Orbital data collection and digital image processing}

Three scenes of images from the Landsat 5 satellite (bands 1, 2, 3, 4, 5, and 7), corresponding to the TM sensor, orbit 222 and point 79 were used and acquired from the image catalog of the National Institute for Space Research (INPE, 2013), obtained in October of 1991, 2001, and 2011. The satellite images with spatial resolution of 30 meters were georeferenced in the IDRISI Selva $17.0^{\circ}$ software (Eastman, 2012) using the Universal Transversa de Mercator (UTM) projection, WGS 84 datum, and South 22 spindle 41 points of control, collected in the field with a Global Positioning System (GPS). The RGB composition consisted of a combination of bands 3,4 and 5 of the electromagnetic spectrum, TM sensor, and digital image processing was performed to improve color, brightness and contrast enhancement.

\subsection{Sampling units and classification of land use and cover}

Land use and land cover classes were determined and a database containing 180 sample patterns was developed to collect representative terrestrial sample patterns. For each sampling pattern, the use of the site, photographic record, and geographic location were established to compose the database. Sample units (soil samples and land cover) were collected in an ideal quantity for each image of the time series for the classification process (approximately $10 \%$ of the image area).

The supervised classification of the pixel-to-pixel satellite images followed the Maximum Likelihood (MAXLIKE) method, a technique proposed by Lee \& Grunes (1992). Six land use and land cover classes were categorized: agriculture, urbanized area, water bodies, pasture, exposed soil, and native vegetation. Land uses, agriculture, and exposed soil were aggregated, and agricultural uses termed to assess changes in the region's landscape. This aggregation (agriculture and soil exposed) is due to the acquisition dates of the images (spring in the Southern Hemisphere), the procedures for collecting the sample units, and even for presenting different photointerpretation parameters (texture, hue, color, and roughness), and these uses represent the same land use and land cover class.

The Kappa Coefficient (Cohen, 1960) obtained from applying the Errmat module of the IDRISI Selva $17.0^{\circ}$ software (Eastman, 2012) was used to evaluate the accuracy of the classifications. The Kappa coefficients obtained for the three classifications of this study presented excellent accuracy, with Kappa coefficients of: $1991-0.94$ (94\%), $2001-0.96$ (96\%), and $2011-0.90$ (90\%).

The classification of land use and land cover classes was adapted from the systematic classification proposed by the Land Use Technical Manual of the IBGE (IBGE, 2013). MapInfo Professional $9.5^{\circ}$ software was developed with thematic land use and land cover maps.

\subsection{Data analysis}

Geographic units limited by the municipalities of the region in this study were considered as sample units. Thus, the area percentages of each land use and land cover in each location were used as variables. Therefore, Variance Analysis (One-way ANOVA) was used with Tukey posterior test to evaluate the difference between the area percentage of each land use and cover over the three studied periods.

Principal component analysis (PCA) was used to order the sample units according to the variation of the quantified variables in an attempt to synthesize the variability of the sample units into a smaller number of dimensions. The spatial classification of the municipalities was then proposed from this ordinance according to the geographical position in the region.

Next, a principal coordinate analysis (PCoA) was used from this classification, and a new ordering of the sample units was performed. The centroid and the respective distance between the point of the sample unit and the centroid of this group were subsequently defined for each group (northern portion and southern portion). The distances of the centroids were compared by ANOVA. The analyses were performed in the statistical $R$ environment ( $R$ Core Team, 2015) using the "vegan" functions (Oksanen et al., 2010).

\section{RESULTS}

The spatial/temporal analysis of land use and land cover between 1991, 2001, and 2011 showed that trends in the landscape in the region during the last two decades are related to a decrease in area occupied by agricultural uses (agriculture and exposed soil), and by an increase in area occupied by land uses of native vegetation, pasture, and urbanized area. A predominance of agricultural uses in the region was verified during all the analyzed periods (Figure 2).

Among the land uses and cover quantified for the studied period, native vegetation and pasture presented a total increase in area of $8.47 \%$ and $12.24 \%$, respectively, over this 20 years $\left(\mathrm{F}_{(2.90)}=9.41 p<0.001 ; \mathrm{F}_{(2.90)}=17.31 p<0.001\right)$ (Figure 3). On the other hand, agricultural uses (agriculture and exposed 
soil) reduced their occupation areas during the study period, totaling $22.13 \%\left(\mathrm{~F}_{(2.90)}=20.36 p<0.001\right)$ (Figure 3). The urbanized areas did not show an increase in area during the studied period $\left(\mathrm{F}_{(2.90)}=0.55 p=0.57\right)$ (Figure 3 ).

The total variation in land use and land cover in municipalities during the study period was $89.2 \%$ in the first two main components
(Figure 4). Agricultural uses positively ordered municipalities in PC1 (76.1\%), while native vegetation and pasture were negatively ordered in PC1. The area with native vegetation cover and pasture was responsible for the ordering in PC2 (13.1\%). The ordering of the municipalities was observed by this analysis according to the agriculture and exposed soil percentage.

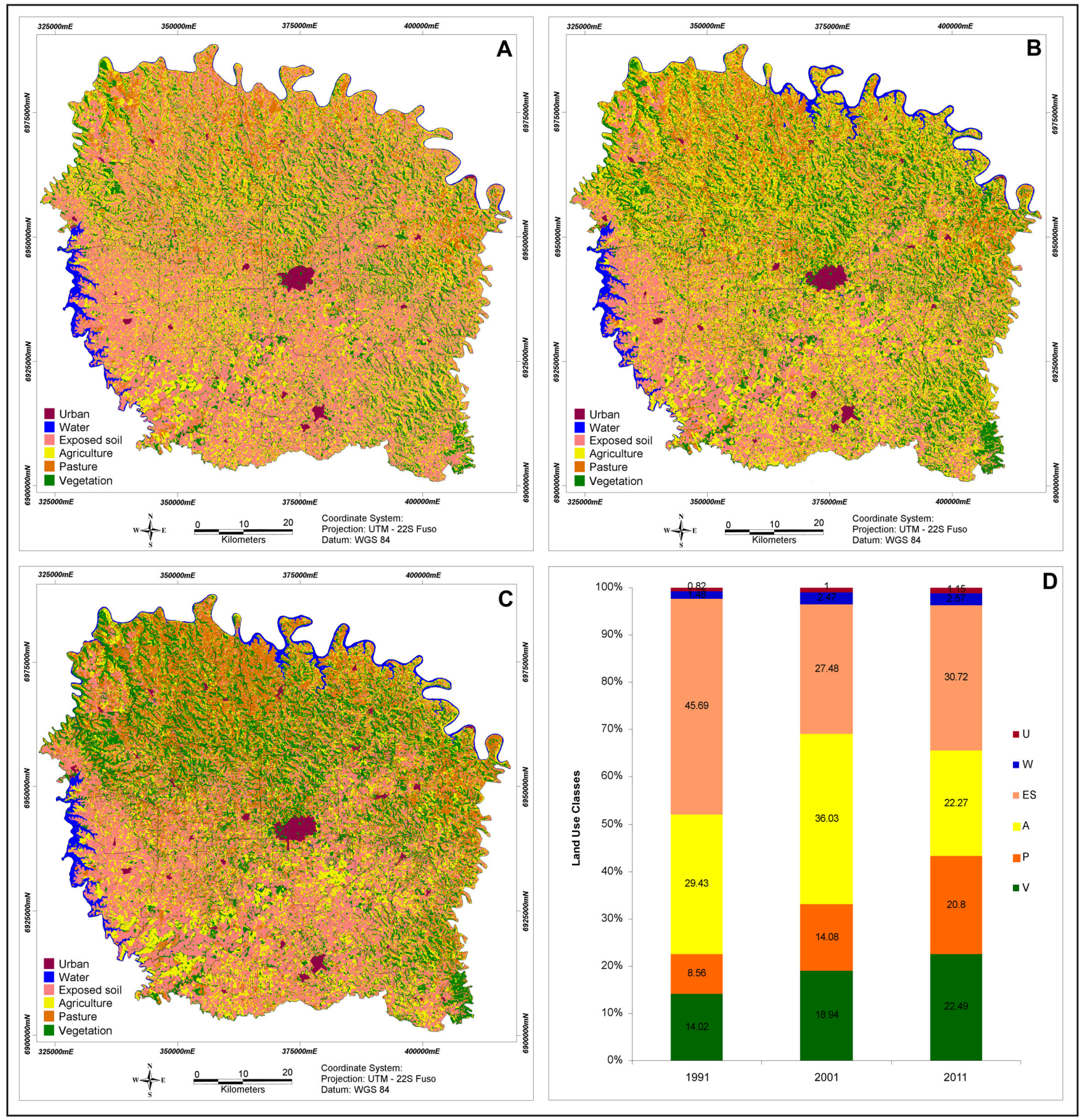

Figure 2. Land use and cover between the years of: (a) 1991; (b) 2001; (c) 2011; and (d) temporal variation and occupied percentage for each land use and cover of the northern region of Rio Grande do Sul, Brazil.

UA: urbanized area; WB: water bodies; ES: exposed soil; A: agriculture; P: pasture; NV: native vegetation. 

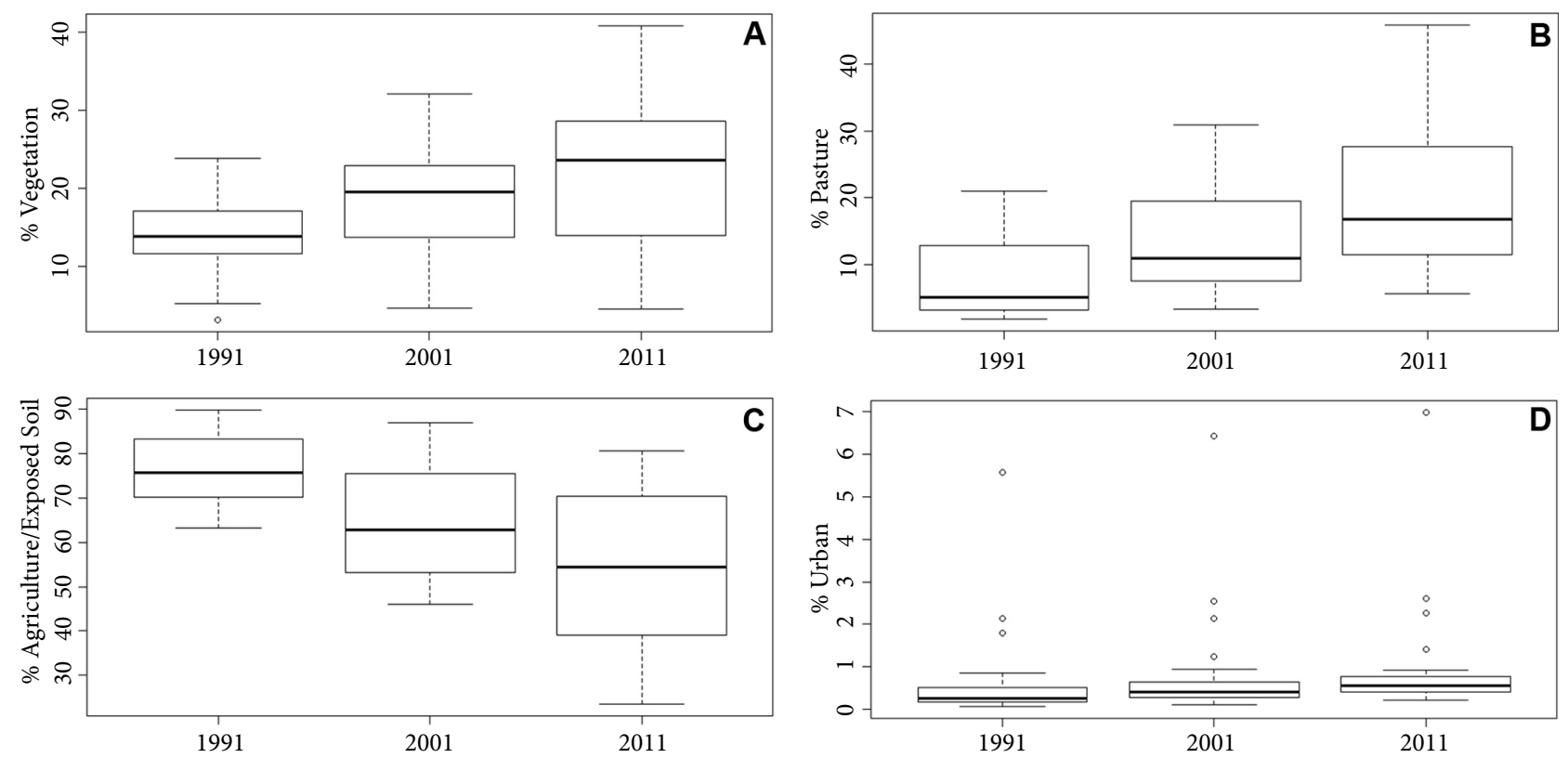

Figure 3. Variation and percentage occupied by each class of land use and land cover: (a) native vegetation; (b) pasture; (c) agriculture and soil exposure; and (d) urbanized area, between 1991 and 2011 in the northern region of Rio Grande do Sul, Brazil.

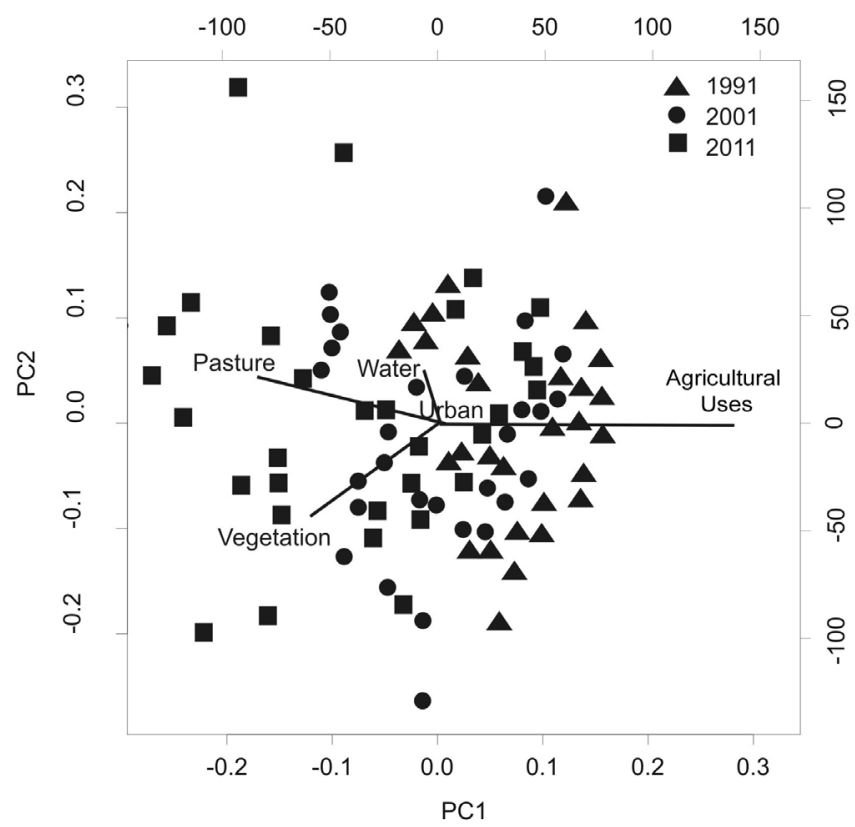

Figure 4. Principal components analysis (PCA) with land use and land cover variables in the 31 municipalities of the northern region of Rio Grande do Sul between 1991, 2001, and 2011.

The total set of municipalities was classified in the southern portion (larger agricultural area) and northern portion (larger area of native vegetation and pasture). In this context, a greater variation was observed in the municipalities of the northern portion (centroid average $=17.3$ ) in relation to the southern portion $($ centroid mean $=11.8)\left(\mathrm{F}_{(1.91)}=12.49 p<0.001\right)$
(Figure 5). These landscape dynamics in the northern portion were generated by the reduction in agricultural areas and the increase in pasture areas and native vegetation. On the other hand, the lower variability in the landscape in the southern portion occurred due to the constancy of agricultural areas during the studied period. 


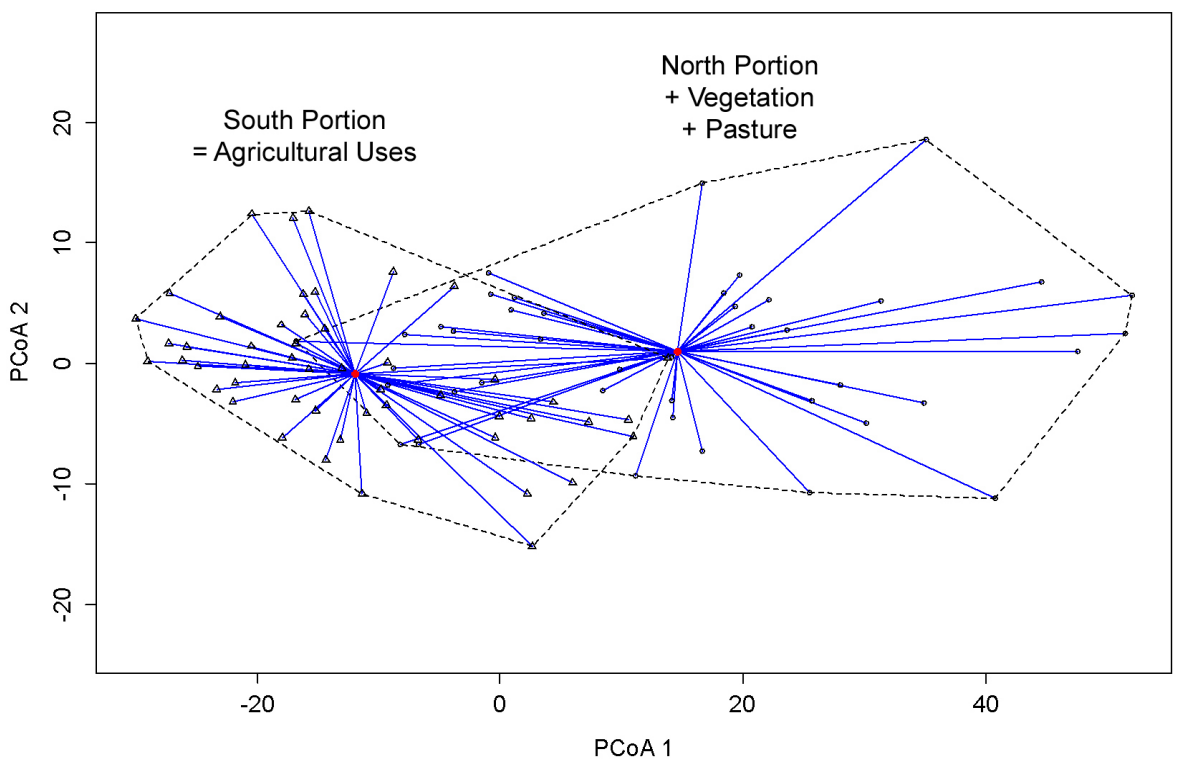

Figure 5. Analysis of principal coordinates demonstrating the variability in the landscape in the 31 municipalities of the northern region of Rio Grande do Sul, between 1991, 2001, and 2011.

\section{DISCUSSION}

The results of this study demonstrate that the region undergoes a transformation process in the composition and configuration of its landscape due to changes in land use and land cover. When anthropogenic land use and land cover changes are associated with economic activities and public policies on a regional scale, they have direct effects on the composition and structure of the landscape (Lu et al., 2003; Turner, 1989).

The present study verified that the expansion of the native vegetation and pasture areas (northern portion of the region) during the study period are related to the rural exodus and the replacement of agricultural areas with less capacity for agriculture mechanization and in sloping relief. The substitution or abandonment of agricultural land is currently seen as the main factor in reducing forest deforestation and natural recovery (Grau et al., 2003; Parsons, 2014). In addition, agricultural land substitution processes generally occur as a result of the high costs for agricultural cultivation in these areas, resulting in recovery of the natural environment.

Changes in the regional landscape may be related to the introduction of new production and soil management techniques which have promoted agricultural mechanization associated with monoculture, no-tillage, crop rotation, intensified use of chemical inputs, as well as selection and breeding of seeds (Benetti, 2010; Casão et al., 2012). Other factors such as environmental legislation, implementation of agricultural and environmental programs, as well as the maintenance, increase and regional management of current and future areas of native vegetation may have contributed to these changes.

The increase in urbanized areas between 1991 and 2011 results from the rural exodus and urban sprawl processes in the region. This result is mainly due to the urban expansion of the municipality of Erechim (commercial and industrial area in the region), which currently comprises a population of 103,437 inhabitants (46.4\%) of the total region, $90 \%$ of which is urban. This scenario is corroborated by data from the IBGE Demographic Census of 1991, 2000, and 2010, and population estimates for 2019, which evidenced an increase in the urban population and a reduction in the region's rural population (IBGE, 1991, 2000, 2010, 2019).

Rural exodus leads to an increase in urban population density, often triggering an urban expansion of the region's municipalities, especially those which increase the urban perimeter when related to providing services and jobs in the tertiary sector. This characteristic proves the process of reducing the population of small municipalities, especially of its young rural population towards the urban centers (Erechim in particular) (Piran, 2015). According to Piran $(2001,2015)$, rural exodus in the region is the main socioeconomic factor that contributed to the process of changing the landscape over time.

The ongoing process of land substitution and the reduced rural population are common trends and have subsequent socioeconomic and environmental implications, such as 
increased natural vegetation areas, as well as reduced areas for agricultural use and exploitation of natural resources (Melendez-Pastor et al., 2014). The concentration and expansion of agriculture are currently related to fertile flat areas suitable for modern agriculture with high productivity, while areas with declining land and less agricultural ability tend to reduce land use and land cover, and are associated with a decrease in the rural population (Aide \& Grau, 2004; Izquierdo \& Grau, 2009).

The increase in area occupied by pastures is related to new economic activities, especially beef cattle and milk, as also verified in the livestock production of the region available in the Agricultural census of 2006 (IBGE, 2006). These activities are verified in municipalities where the technology associated to monoculture presents certain restrictions to apply its maximum productive potential, mainly due to the topography and the small size of the rural properties (family and small farms).

Throughout the analyzed period (1991 to 2011), forest recovery processes resulted in expansion of native vegetation areas. The study area was and remains subjected to environmental legislation related to the preservation, conservation and management of natural resources, such as the Forest Code (Law No. 4,771 of September 15, 1965) (Brasil, 1965), and the Law on Environmental Crimes (Law No. 9,605 of February 12, 1998) (Brasil, 1998). Currently, other legislation such as the Native Vegetation Protection Law (LPVN), denominated as the New Forest Code (Law No. 12,651 of May 25, 2012) (Brasil, 2012a) and the Rural Environmental Registry (CAR) (Decree No. 7,830 of October 17, 2012) (Brasil, 2012b), linked to the National Information System on the Environment (Sinima), brought several rules of order and use of forest cover, indirectly influencing the spatial and temporal configuration of the natural component of the study area.

The dynamics of forest recovery are due to the substitution of agricultural areas with greater slope, resulting in the natural succession of the native vegetation. Increased forest areas are generally evident in soils with less capacity for agricultural production and areas with steeper gradients (Nainggolan et al., 2012). Thus, when an agricultural land use is abandoned, the process of ecological succession inevitably occurs in these areas, leading to spontaneous regeneration of native vegetation.

Increase and predominance of native vegetation areas in the municipalities located in the eastern and mainly northern portion of the region are related to the larger slopes and are usually characterized by small rural properties. The increase in slope in these areas favors the occurrence of larger forest fragments. More rugged regions tend to have more complex landscapes due to the relief, and less modified by man in relation to flat relief regions (Metzger, 2001).

The results show the percentages of agricultural uses (southern portion of the region) predominating in the region determined the major changes in land use and land cover. This feature proves the region is embedded in a predominantly agricultural matrix. As the world's growing demand for food is the main agricultural expansion agent, this leads to negative impacts on natural remnants (Guida-Johnson \& Zuleta, 2013). This scenario combined with intensifying modern agricultural practices in turn leads to conversion of a complex landscape matrix into a homogeneous system (Geri et al., 2010).

Changes in land use and land cover are combined results of larger scale changes driven by socioeconomic, political, institutional, demographic, and market forces (Lambin \& Meyfroidt, 2010). Change patterns in land use and land cover over long periods of time also vary depending on economic, institutional and social factors (Munteanu et al., 2014).

In the present scenario, the native vegetation of the region is very devastated and fragmented, mainly in the south due to human occupation and implantation of modern agriculture, whereas in the north the rural exodus of small farmers, the sloping relief and restrictions on land use have led to a recovery process of vegetal cover (Piran, 2015). The natural landscape of the region suffers anthropic pressure due to the appropriation process of spaces for large-scale agriculture development. The scenario of higher agricultural production was verified for the municipalities inserted in areas with low slopes (west and mainly southern part of the region) with marked soy, corn, and wheat production. According to the World Bank (Deininger et al., 2011), Brazil is a major agricultural and livestock producer in the world, having the South of Brazil as an agricultural granary.

The forest fragmentation process that occurred prior to this study period and agricultural activity, a predominant component of the landscape of the region, were the determinants for the low occupation of native vegetation in the area. On the other hand, changes in land use and cover during this period, especially the expansion of native vegetation areas, help to form larger forest fragments and positively reflect on ecological sustainability. In the context of land use and land cover trends and socioeconomic globalization, the balance between agriculture development and environmental conservation is important (Grau et al., 2013).

\section{CONCLUSIONS}

The predominant agricultural uses and the development of socioeconomic activities such as replacing agricultural 
areas and rural exodus, associated with environmental legislation in the region are the main factors responsible for generating changes in the structural composition of the landscape. Effects of changes in land use and land cover have directly resulted in reduced agricultural areas and expansion of native vegetation areas, contributing to maintain the natural capital and ecological sustainability of the region.

It should be noted that the region's landscape is currently configured in two scenarios. The landscape located in the eastern and northern portions of the region has a predominance of native vegetation and pasture areas and is inserted in wavy to sloping relief. While the landscape located in the western and southern portions of the region shows a predominance of agricultural uses and a relation to areas with flat sloping gradients.

The database of this study will provide planners and decision makers with tools capable of assisting spatial planning, identifying suitable socioeconomic alternatives and environmental management of the region's land. These results can also be used as subsidies in the elaboration and revision process of municipal environmental plans, as well as in the process of economic ecological zoning. In addition, expanding native vegetation areas reinforces the need for environmental planning and management actions, ensuring the maintenance of these areas, biodiversity conservation, and relevance of the region's native vegetation.

Thus, the main challenge of research on land use and land cover changes is linked to the monitoring process and maintaining continuous data time series capable of generating uninterrupted series of analyses and assessments of trends in the region's landscape and effects of these socioeconomic factors.

\section{ACKNOWLEDGEMENTS}

The authors are grateful for the contributions made by Professor José Eduardo dos Santos of the Universidade Federal de São Carlos (UFSCar) and the group of researchers of the Geoprocessing Laboratory and Environmental Planning (Lageplam) of the Universidade Regional Integrada do Alto Uruguai e das Missões (URI). Luiz Ubiratan Hepp receives financial support from the Conselho Nacional de Desenvolvimento Científico e Tecnológico (CNPq) (process 421632/2016-0) and productivity grant (process 305203/2017-7).

\section{SUBMISSION STATUS}

Received: 6 Jun. 2018

Accepted: 5 Apr. 2019

Associate editor: Marcel Carvalho Abreu

\section{CORRESPONDENCE TO}

\section{Ivan Luís Rovani}

Universidade Regional Integrada do Alto Uruguai e das Missões (URI), Av. Sete de Setembro, 1.621, CEP 99709-910, Erechim, RS, Brasil e-mail: ivanrovani@yahoo.com.br

\section{FINANCIAL SUPPORT}

Coordenação de Aperfeiçoamento de Pessoal de Nível Superior (CAPES) (Finance Code 001).

\section{REFERENCES}

Aide TM, Grau HR. Globalization, migration, and Latin American ecosystems. Science 2004; 305(5692): 1915-1916. 10.1126/ science. 1103179

Alvares CA, Stape JL, Sentelhas PC, Gonçalves JLM, Sparovek G. Koppen's climate classification map for Brazil. Meteorologische Zeitschrift 2013; 22(6): 711-728. 10.1127/0941-2948/2013/0507

Benetti MD. O agronegócio gaúcho entre os anos 1980 e 2008. In: Conceição OAC, Grando MZ, Teruchkin SU, Faria LAE, editors. Três décadas de economia gaúcha: vol. 2, o movimento da produção. Porto Alegre: FEE; 2010. p. 59-92.

Bossard M, Feranec J, Otahel J. Corine land cover technical guide: addendum 2000. Copenhagen: Europen Environment Agency; May 2000. (Technical Report, 40).

Brasil. Lei $\mathrm{n}^{\circ} 4.771$, de 15 de setembro de 1965. Institui o Código Florestal Brasileiro. Diário Oficial da União, Brasília, DF (1965 Sept. 16); Sec. 1: 9529.

Brasil. Lei no 9.605, de 12 de fevereiro de 1998. Lei de Crimes Ambientais. Dispõe sobre as sanções penais e administrativas derivadas de condutas e atividades lesivas ao meio ambiente, e dá outras providências. Diário Oficial da União, Brasília, DF (1998 Feb. 13); Sec. 1: 1.

Brasil. Lei no 12.651 , de 25 de maio de 2012. Dispõe sobre a proteção da vegetação nativa; altera as Leis no 6.938 , de 31 de agosto de 1981, 9.393, de 19 de dezembro de 1996, e 11.428, de 22 de dezembro de 2006; revoga as Leis 4.771, de 15 de setembro de 1965, e 7.754, de 14 de abril de 1989, e a Medida Provisória no 2.166-67, de 24 de agosto de 2001, e dá outras providências. Diário Oficial da União, Brasília, DF (2012a May 28); Sec. 1: 1.

Brasil. Decreto ${ }^{\circ}$ 7.830, de 17 de outubro de 2012. Dispõe sobre o Sistema de Cadastro Ambiental Rural, o Cadastro Ambiental Rural, estabelece normas de caráter geral aos Programas de Regularização Ambiental, de que trata a Lei $n^{\circ} 12.651$, de 25 de maio de 2012; e dá outras providências. Diário Oficial da União, Brasília, DF (2012b Oct. 18); Sec. 1; 5.

Casão R Jr, Araújo AG, Llanillo RF. Plantio direto no Sul do Brasil: fatores que facilitaram a evolução do sistema e o desenvolvimento da mecanização conservacionista. Londrina: Iapar; 2012.

Cohen JA. A coefficient of agreement for nominal scales. Educational and Psychological Measurement 1960; 20(1): 37-46. $10.1177 / 001316446002000104$ 
Decian VS, Zanin EM, Henke-Oliveira C, Rosset-Quadros F, Ferrari C. Uso e ocupação da terra na região Alto Uruguai do Rio Grande do Sul e obtenção de banco de dados relacional de fragmentos de vegetação arbórea. Perspectiva 2009; 33(121): 165-176.

Deininger K, Byerlee D, Lindsay J, Norton A, Selod H, Stickler M. Rising global interest in farmland: can it yield sustainable and equitable benefits? Washington, DC: The World Bank; 2011.

Díaz GI, Nahuelhual L, Echeverría C, Marin S. Drivers of land abandonment in Southern Chile and implications for landscape planning. Landscape and Urban Planning 2011; 99(3-4): 207-217. 10.1016/j.landurbplan.2010.11.005

Eastman JR. IDRISI Selva Manual. Worcester: Clark University; 2012.

Figueiredo J, Pereira HM. Regime shifts in a socio-ecological model of farmland abandonment. Landscape Ecology 2011; 26: 737-749. 10.1007/s10980-011-9605-3

Geri F, Rocchini D, Chiarucci A. Landscape metrics and topographical determinants of large-scale forest dynamics in a Mediterranean landscape. Landscape and Urban Planning 2010; 95(1-2): 46-53. 10.1016/j.landurbplan.2009.12.001

Gerlak AK. Policy interactions in human-landscape systems. Environmental Management 2014; 53(1): 67-75. 10.1007/s00267013-0068-y

Grau R, Aide TM, Zimmerman JK, Thomlinson JR, Helmer E, Zou $\mathrm{X}$. The ecological consequences of socioeconomic and land use change in postagriculture Puerto Rico. BioScience 2003; 53(12): 1159-1168. 10.1641/0006-3568(2003)053[1159:TECOSA]2.0.CO;2

Grau R, Kuemmerle T, Macchi L. Beyond "land sparing versus land sharing": environmental heterogeneity, globalization and the balance between agricultural production and nature conservation. Current Opinion in Environmental Sustainability 2013; 5(5): 477483. $10.1016 /$ j.cosust.2013.06.001

Guida-Johnson B, Zuleta GA. Land-use land-cover change and ecosystem loss in the Espinal ecoregion, Argentina. Agriculture, Ecosystems \& Environment 2013; 181: 31-40. 10.1016/j. agee.2013.09.002

Hernández A, Miranda M, Arellano EC, Saura S, Ovalle C. Landscape dynamics and their effect on the functional connectivity of a Mediterranean landscape in Chile. Ecological Indicators 2015; 48 : 198-206. 10.1016/j.ecolind.2014.08.010

Instituto Brasileiro de Geografia e Estatística - IBGE. Censo demográfico 1991 [Internet]. Rio de Janeiro: IBGE; 1991 [cited 2018 Feb. 22]. Available from: https://bit.ly/3bRMesP

Instituto Brasileiro de Geografia e Estatística - IBGE. Censo demográfico 2000 [Internet]. Rio de Janeiro: IBGE; 2000 [cited 2018 Feb. 22]. Available from: https://bit.ly/3ayDDKZ

Instituto Brasileiro de Geografia e Estatística - IBGE. Censo agropecuário 2006: Brasil, grandes regiões e unidades da federação [Internet]. Rio de Janeiro: IBGE; 2006 [cited 2018 Mar. 14]. Available from: https://bit.ly/2ISOkMs

Instituto Brasileiro de Geografia e Estatística - IBGE. Censo demográfico 2010 [Internet]. Rio de Janeiro: IBGE; 2010 [cited 2018 Feb. 22]. Available from: https://bit.ly/38W0IWy

Instituto Brasileiro de Geografia e Estatística - IBGE. Manual técnico de uso da terra [Internet]. 3rd ed. Manuais Técnicos em Geociências.
Rio de Janeiro: IBGE; 2013 [cited 2018 Mar. 14]. (Manuais Técnicos em Geociências, 7). Available from: https://bit.ly/2Qls2qW

Instituto Brasileiro de Geografia e Estatística - IBGE. Estimativas da população [Internet]. Rio de Janeiro: IBGE; 2019 [cited 2020 Mar. 28]. Available from: https://bit.ly/2wRfdxT

Instituto Nacional de Pesquisas Espaciais - INPE. Aquisição de imagens de satélite TM/Landsat5 [Internet]. São José dos Campos: INPE; 2013 [cited 2017 Oct. 11]. Available from: https://bit. ly/2TW3E1d

Izquierdo AE, Grau HR. Agriculture adjustment, land-use transition and protected areas in Northwestern Argentina. Journal of Environmental Management 2009; 90(2): 858-865. 10.1016/j. jenvman.2008.02.013

Lambin EF, Meyfroidt P. Land use transitions: socio-ecological feedback versus socio-economic change. Land Use Policy 2010; 27(2): 108-118. 10.1016/j.landusepol.2009.09.003

Lee JS, Grunes MR. Feature classification using multi-look polarimetric SAR imagery. In: International Geoscience and Remote Sensing Symposium; 1992; Houston. New York: IEEE; 1992. p. 77-79. 10.1109/IGARSS.1992.576631

Liu Y. Introduction to land use and rural sustainability in China. Land Use Policy 2018; 74: 1-4. 10.1016/j.landusepol.2018.01.032

Lu L, Li X, Cheng G. Landscape evolution in the middle Heihe river basin of north-west China during the last decade. Journal of Arid Environments 2003; 53(3): 395-408. 10.1006/jare.2002.1032

Melendez-Pastor I, Hernández EI, Navarro-Pedreño J, Gómez I. Socioeconomic factors influencing land cover changes in rural areas: the case of the Sierra de Albarracín (Spain). Applied Geography 2014; 52: 34-45. 10.1016/j.apgeog.2014.04.013

Metzger JP. O que é ecologia de paisagens? Biota Neotropica [Internet] 2001 [cited 2020 Mar. 17]; 1(1/2): 1-9. Available from: https://bit.ly/2IPX0mO

Munteanu C, Kuemmerle T, Boltiziar M, Butsic V, Gimmi U, Halada $\mathrm{L}$ et al. Forest and agricultural land change in the Carpathian region: a meta-analysis of long-term patterns and drivers of change. Land Use Policy 2014; 38: 685-697. 10.1016/j.landusepol.2014.01.012

Nainggolan D, De Vente J, Boix-Fayos C, Termansen M, Hubacek K, Reed MS. Afforestation, agricultural abandonment and intensification: competing trajectories in semi-arid Mediterranean agro-ecosystems. Agriculture, Ecosystems \& Environment 2012; 159: 90-104. 10.1016/j.agee.2012.06.023

Oksanen J, Blanchet FG, Kindt R, Legendre P, O’Hara RG, Simpson GL et al. Vegan: community ecology package. R package version 1.17-5 [software]. 2010 Dec. 18 [cited 2015 Mar. 2]. Available from: https://bit.ly/33pMXhC.

Oliveira-Filho AT, Budke JC, Jarenkow JA, Eisenlohr PV, Neves DRM. Delving into the variations in tree species composition and richness across South American subtropical Atlantic and Pampean forests. Journal of Plant Ecology 2015; 8(3): 242-260. 10.1093/jpe/ rtt058

Ottinger M, Kuenzer C, Liu G, Wang S, Dech S. Monitoring land cover dynamics in the Yellow river delta from 1995 to 2010 based on Landsat 5 TM. Applied Geography 2013; 44: 53-68. 10.1016/j. apgeog.2013.07.003 
Parcerisas L, Marull J, Pino J, Tello E, Coll F, Basnou C. Land use changes, landscape ecology and their socioeconomic driving forces in the Spanish Mediterranean coast (El Maresme County, 1850-2005). Environmental Science \& Policy 2012; 23: 120-132. 10.1016/j.envsci.2012.08.002

Parsons AJ. Abandonment of agricultural land, agricultural policy and land degradation in Mediterranean Europe. In: Mueller EN, Wainwright J, Parsons AJ, Turnbull L, editors. Patterns of land degradation in drylands. Netherlands: Springer; 2014. p. 357-366.

Peterson JM, Caldas MM, Bergtold JS, Sturm BS, Graves RW, Earnhart $\mathrm{D}$ et al. Economic linkages to changing landscapes. Environmental Management 2014; 53(1): 55-66. 10.1007/s00267-013-0116-7

Piran N. Agricultura familiar: lutas e perspectivas no Alto Uruguai. Erechim: EdiFAPES; 2001.

Piran N. Contribuição à caracterização do Alto Uruguai (RS): breve releitura e novos desafios. Perspectiva 2015; 39(4): 53-64.

R Core Team. R: a language and environment for statistical computing. Vienna: R Foundation for Statistical Computing; 2015 [cited 2015 Feb. 10]. Available from: http://www.R-project.org/

Rudel TK. Tree farms: driving forces and regional patterns in the global expansion of forest plantations. Land Use Policy 2009; 26(3): 545-550. 10.1016/j.landusepol.2008.08.003
Simon ALH, Trentin G. Elaboração de cenários recentes de uso da terra utilizando imagens do Google Earth.Ar@cne: revista electrónica de recursos en internet sobre geografía y ciencias sociales 2009; (116).

Su S, Ma X, Xiao R. Agricultural landscape pattern changes in response to urbanization at ecoregional scale. Ecological Indicators 2014; 40: 10-18. 10.1016/j.ecolind.2013.12.013

Turner BL II. Land change science. In: Kitchin R, Thrift N, editors. International encyclopedia of human geography. Oxford: Elsevier; 2009. p. 107-111.

Turner BL II, Lambin EF, Reenberg A. The emergence of land change science for global environmental change and sustainability. Proceedings of the National Academy of Sciences of the United States of America 2007; 104(52): 20666-20671. 10.1073/pnas.0704119104

Turner MG. Landscape ecology: the effect of patterns on process. Annual Review of Ecological Systems 1989; 20: 171-191. 10.1146/ annurev.es.20.110189.001131

Zhang J, Niu J, Buyantuev A, Wu J. A multilevel analysis of effects of land use policy on land-cover change and local land use decisions. Journal of Arid Environments 2014; 108: 19-28. 10.1016/j. jaridenv.2014.04.006 